\title{
Dose response relationships and interference of simultaneous skin tests in delayed hypersensitivity
}

\author{
A. M. M. JOKIPII AND LIISA JOKIPII \\ From the Department of Serology and Bacteriology, University of Helsinki, Helsinki, Finland
}

SYNOPSIS The relationship between the intensity of the delayed hypersensitivity reaction and the dose of antigen used for its elicitation change with time after sensitization. At three weeks the reactions to $100 \mu \mathrm{g}$ of egg albumen were little different from those to $1 \mu \mathrm{g}$ but at 14 weeks $100 \mu \mathrm{g}$ gave much stronger reactions. This means that to follow the development of a delayed hypersensitivity response several antigen doses should be used.

If two skin tests were performed simultaneously in the same individual, the stronger one suppressed the weaker one, regardless of whether two different doses of the same antigen or two different antigens were used. Consequently, not more than one skin test at a time should be performed.

Delayed hypersensitivity is detected by intradermal antigen injection in both clinical and experimental immunology. Skin reactivity can be quantitatively approached either by evaluation of the erythema and induration provoked by a given dose of antigen or by determination of the smallest amount of antigen eliciting a positive reaction.

The characteristic mononuclear cell infiltrate of delayed hypersensitivity is hematogenous and contains a minority of specifically sensitized cells (Kosunen, Waksman, Flax, and Tihen, 1963; McCluskey, Benacerraf, and McCluskey, 1963). Studies of correlates in vitro of delayed hypersensitivity have shown that the underlying sequence of events can be divided in a specific and nonspecific part. At first antigen is recognized by specifically sensitized lymphocytes, and later nonspecific lymphocytes; soluble lymphocyte products and macrophages complete the visible reactions (Pick and Turk, 1972; Ruddle, 1972).

In the hope of more results, several skin tests are often performed in one individual at the same time. The aim of this study was to confirm our experience that simultaneous skin reactions interfere and, therefore, do not reveal the true reactivity.

\section{Materials and Methods}

ANIMALS AND SENSITIZATION

White male guinea pigs weighing 400 to $500 \mathrm{~g}$

Received for publication 5 July 1973. were used. A saline solution of hen egg albumen (Sigma, St Louis, Missouri) was mixed $(1: 1)$ with complete Freund's adjuvant (CFA) consisting of $1.5 \mathrm{ml}$ of Arlacel A (Mannide Monooleate, Atlas Powder Co, Wilmington, Delaware), $8.5 \mathrm{ml}$ of Bayol F (Esso), and $60 \mathrm{mg}$ of heat-killed tubercle bacilli. The animals were injected intradermally in the neck with $0.1 \mathrm{ml}$ of the adjuvant emulsion containing $5 \mu \mathrm{g}$ of egg albumen.

\section{SKIN TESTING}

The guinea pigs were injected in the preshaven flank with $0.1 \mathrm{ml}$ volumes of saline solutions of egg albumen or tuberculin-purified protein derivative (PPD) (Purified Tuberculin, Statens Seruminstitut, Copenhagen). The skin reactions were recorded 24 hours later. The erythema was measured with a ruler, and the induration was evaluated from - to ++++ by palpation between two fingers and, in part of the experiment, it was measured with a caliper as the increase in skin double thickness (recorded immediately before the intradermal injection and 24 hours afterwards).

\section{STATISTICAL TREATMENT}

The arithmetic means of numerical values were compared in Student's $t$ test. The median was chosen as the central value for the degrees of induration, which were compared in the nonparametric rank-sum test (Dixon and Massey, 1957). The compared groups were tested at the same time. 


\section{Results}

DOSE RESPONSE RELATIONSHIP IN

DELAYED SKIN REACTIVITY

Groups of guinea pigs were sensitized with $5 \mu \mathrm{g}$ of egg albumen in complete Freund's adjuvant. Three weeks later they were injected intradermally with $100 \mu \mathrm{g}, 10 \mu \mathrm{g}, 1 \mu \mathrm{g}, 100 \mathrm{ng}$, or $10 \mathrm{ng}$ of egg albumen. A positive dose response relationship was found, but a tenfold (unpublished) or hundredfold change in the antigen dose caused surprisingly little change in both the erythema and induration at 24 hours (table I). Fourteen weeks after sensitization the reactivity was more clearly related to the dose of egg albumen (table II).

INTERFERENCE OF SIMULTANEOUS DELAYED REACTIONS TO TWO DOSES

Guinea pigs were skin tested with various doses of egg albumen simultaneously with $100 \mu \mathrm{g}$. The strong 24-hour reaction to $100 \mu \mathrm{g}$ of egg albumen suppressed significantly the reactions to lower doses of the same antigen, as compared with similar tests performed alone (table I). A 1000-fold dose of egg albumen was needed to detect positive reactions under the influence of the simultaneously injected $100 \mu \mathrm{g}$. Two tests with $100 \mu \mathrm{g}$ did not suppress each other significantly (table I).
INTERFERENCE OF DELAYED REACTIONS TO DIFFERENT ANTIGENS

Fourteen weeks after sensitization with $5 \mu \mathrm{g}$ of egg albumen in complete Freund's adjuvant,, guinea pigs were skin tested with $5 \mu \mathrm{g}$ of egg albumen들 or $10 \mu \mathrm{g}$ of PPD either alone or simultaneously with $100 \mu \mathrm{g}$ of egg albumen. Table II shows that the strong delayed reaction suppressed significantly尺 the weaker ones to both egg albumen and PPD to roughly the same extent.

\section{Discussion}

The present data show that (a) the dose responsd relationship in the elicitation of delayed skinio reactivity changes with time after sensitization (b) stronger delayed reactions suppress simultane- ously developing weaker ones; and (c) the sup-? pression is not antigen specific. The practicat significance of these findings is clear: not mored than one skin test should be performed at a time $\underset{\mathbb{D}}{\stackrel{D}{0}}$

Three weeks after sensitization, raising the in 3 tradermal dose of egg albumen from 1 to $100 \mu \mathrm{g}$ had little effect on the intensity of the subsequent delayed reaction. At 14 weeks, $100 \mu$ g gave markegh stronger reactions than $5 \mu \mathrm{g}$. This suggests traf there is a limiting factor (other than the antigen

\begin{tabular}{|c|c|c|c|c|}
\hline \multicolumn{2}{|c|}{ Skin Test } & \multicolumn{2}{|c|}{ Delayed Skin Reactivity } & \multirow{2}{*}{$\begin{array}{l}\text { Value } \\
\text { of } P\end{array}$} \\
\hline \multicolumn{2}{|c|}{ Dose of Egg Albumen } & \multirow{2}{*}{$\begin{array}{l}\text { Test Alone } \\
25: 1 \\
2+14 \pm 0 \cdot 18 \\
19\end{array}$} & \multirow[t]{2}{*}{$\begin{array}{l}\text { Test Simultaneously with } \\
100 \mu \mathrm{g} \text { of Egg Albumen }\end{array}$} & \\
\hline $100 \mu \mathrm{g}$ & $\begin{array}{l}\text { Er } \\
\text { Ind } \\
\text { Th } \\
\text { No. }\end{array}$ & & & $\begin{array}{l}>0.05 \\
>0.05 \\
>0.05\end{array}$ \\
\hline $10 \mu \mathrm{g}$ & $\begin{array}{l}\text { Er } \\
\text { Ind } \\
\text { Th } \\
\text { No. }\end{array}$ & $\begin{array}{l}\text { ND } \\
\text { ND } \\
\text { ND } \\
\text { ND }\end{array}$ & $\begin{array}{l}17 \pm 2 \\
+ \\
0 \cdot 80 \pm 0 \cdot 33 \\
10\end{array}$ & \\
\hline $1 \mu \mathrm{g}$ & $\begin{array}{l}\text { Er } \\
\text { Ind } \\
\text { Th } \\
\text { No. }\end{array}$ & $\begin{array}{l}22 \pm 1 \\
- \text { to }++ \\
1.96 \pm 0.03 \\
6\end{array}$ & $\begin{array}{l}9 \pm 1 \\
- \\
0 \cdot 35 \pm 0 \cdot 14 \\
10\end{array}$ & $\begin{array}{l}<0.001 \\
<0.001 \\
<0.001\end{array}$ \\
\hline $100 \mathrm{ng}$ & $\begin{array}{l}\text { Er } \\
\text { Ind } \\
\text { No. }\end{array}$ & $\begin{array}{l}\text { ND } \\
\text { ND } \\
\text { ND }\end{array}$ & $\begin{array}{l}\frac{1}{6} \\
\frac{6}{}\end{array}$ & \\
\hline $10 \mathrm{ng}$ & $\begin{array}{l}\text { Er } \\
\text { Ind } \\
\text { Th } \\
\text { No. }\end{array}$ & $\begin{array}{l}11 \pm 1 \\
\div \\
0.94 \pm 0.09 \\
7\end{array}$ & $\begin{array}{l}0 \pm 0 \\
- \\
\text { ND } \\
6\end{array}$ & $\begin{array}{l}<0.001 \\
<0.001\end{array}$ \\
\hline
\end{tabular}

Table I Interference of delayed skin reactions to two doses of egg albumen in guinea pigs sensitized three weeks earlier

$\mathrm{Er}=$ mean diameter of erythema \pm standard error $(\mathrm{mm})$, Ind $=$ median degree of induration, Th $=$ mean increase in skin double thicknes \pm standard error $(\mathrm{mm})$, No. $=$ number of guinea pigs, ND $=$ not done. 


\begin{tabular}{|c|c|c|c|c|}
\hline \multirow{2}{*}{$\frac{\text { Skin Test }}{\text { Antigen }}$} & & \multicolumn{2}{|c|}{ Delayed Skin Reactivity } & \multirow{3}{*}{$\begin{array}{l}\text { Value } \\
\text { of } P\end{array}$} \\
\hline & & Test Alone & $\begin{array}{l}\text { Test Simultaneously with } \\
100 \mu \mathrm{g} \text { of Egg Albumen }\end{array}$ & \\
\hline Egg albumen $100 \mu g$ & $\begin{array}{l}\text { Er } \\
\text { Ind } \\
\text { Th } \\
\text { No. }\end{array}$ & $\begin{array}{l}29.4 \pm 1.4 \\
+++ \\
2.62 \pm 0.22 \\
14\end{array}$ & $\begin{array}{l}\text { ND } \\
\text { ND } \\
\text { ND } \\
\text { ND }\end{array}$ & \\
\hline Egg albumen $5 \mu \mathrm{g}$ & $\begin{array}{l}\text { Er } \\
\text { Ind } \\
\text { Th } \\
\text { No. }\end{array}$ & $\begin{array}{l}24.1 \pm 1.0 \\
+ \text { to }++ \\
1.97 \pm 0.23 \\
9\end{array}$ & $\begin{array}{l}14 \cdot 3 \pm 1 \cdot 2 \\
+ \\
0 \cdot 80 \pm 0.17 \\
9\end{array}$ & $\begin{array}{l}<0.001 \\
<0.001 \\
<0.001\end{array}$ \\
\hline PPD $10 \mu \mathrm{g}$ & $\begin{array}{l}\text { Er } \\
\text { Ind } \\
\text { Th } \\
\text { No. }\end{array}$ & $\begin{array}{l}17.0 \pm 1.2 \\
+ \\
1.05 \pm 0.29 \\
5\end{array}$ & $\begin{array}{l}12.4 \pm 0.8 \\
- \\
0.39 \pm 0.17 \\
5\end{array}$ & $\begin{array}{l}<0.05 \\
<0.05 \\
>0.05\end{array}$ \\
\hline
\end{tabular}

Table II Nonspecificity of the interference of delayed reactions to two skin tests in guinea pigs sensitized fourteen weeks earlier

$\mathrm{Er}=$ mean diameter of erythema \pm standard error $(\mathrm{mm}), \mathrm{Ind}=$ median degree of induration, $\mathrm{Th}=$ mean increase in skin double thickness \pm standard error $(\mathrm{mm})$, No. $=$ number of guinea pigs, $\mathrm{ND}=$ not done.

at the early stages of immunization. The finding further shows that, in studies of the time course of delayed hypersensitivity responses, the antigen dose selected to monitor the reactivity may influence the results. Higher doses are likely to reveal an increasing sensitivity, while lower doses reach a plateau relatively early.

The simultaneous injection of $100 \mu \mathrm{g}$ of egg albumen suppressed the delayed skin reactions to lower doses of egg albumen. This confirms the earlier similar finding with tuberculin (Baer and Kolb, 1967). The phenomenon is probably related to desensitization, the specific suppression of delayed skin reactivity after challenge with a large antigen dose (Uhr and Pappenheimer, 1958; reviewed by Jokipii, 1972). Desensitization can also be achieved by a challenge simultaneously with skin testing or a couple of hours afterwards (Uhr and Pappenheimer, 1958).

In the present study the delayed reactions to PPD were equally suppressed by the injection of egg albumen, which shows that the limiting factor is not the population of antigen-sensitive cells but rather the nonspecific amplifying mechanism. During a couple of days after desensitization, a nonspecific suppression of delayed hypersensitivity to other antigens has been observed (Uhr and Pappenheimer, 1958; Jokipii, 1970). As two simultaneous doses of $100 \mu \mathrm{g}$ of egg albumen did not suppress each other, it seems that enough cells are available to form two infiltrates. This interpretation is supported by the recent finding that desensitized animals respond normally to exogenous skin reactive factor during the initial period of nonspecific anergy (Dwyer and Kantor, 1973).
The apparent lack of a dose response relationship in guinea pigs, which have the potential to form two strong infiltrates, may be accounted for by assuming that much more than a doubling of the stimulus is needed to produce a detectable increase in the reaction. This is supported by the finding that, although 100,10 , and $1 \mu \mathrm{g}$ of egg albumen in separate individuals gave reactions of comparable intensity, the stimuli may have been markedly different, because the weaker reactions were suppressed, when the $100 \mu \mathrm{g}$ was injected into the same animal.

This study was supported by a grant from the Finnish National Research Council for Medical Sciences.

The authors wish to thank Mrs Maire Laakso, Mrs Maire Nurmi, Mrs Eine Virolainen, and Miss Eija Korhonen for excellent technical assistance.

\section{References}

Baer, H., and Kolb, R. W. (1967). Suppression of the tuberculin reaction by high concentrations of tuberculin and the relationship of this phenomenon to the potency assay of tuberculin. J. Immunol., 98, 1015-1019.

Dixon, W. J., and Massey, F. J., Jr. (1957). Introduction to Statistical Analysis, 2nd ed. McGraw-Hill, New York.

Dwyer, J. M., and Kantor, F. S. (1973). Regulation of delayed hypersensitivity. Failure to transfer delayed hypersensitivity to desensitized guinea pigs. J. exp. Med., 137, 32-41.

Jokipii, L. (1970). Disappearance of the delayed hypersensitivity reaction after intravenous antigen injection in the rat and guinea pig. Ann. Med. exp. Fenn., 48, 226-233.

Jokipii, L. (1972). Studies on desensitization in delayed hypersensitivity. Thesis, University of Helsinki.

Kosunen, T. U., Waksman, B. H., Flax, M. H., and Tihen, W. S. (1963). Radioautographic study of cellular mechanisms in delayed hypersensitivity. I. Delayed reactions to tuberculin and purified proteins in the rat and guinea-pig. Immunology, 6, 276-290. 
McCluskey, R. T., Benacerraf, B., and McCluskey, J. W, (1963) Studies on the specificity of the cellular infiltrate in delayed hypersensitivity reactions. J. Immunol., 90, 466-477.

Pick, E., and Turk, J. L. (1972). The biological activities of soluble lymphocyte products. Clin. exp. Immunol., 10, 1-23.
Ruddle, N. H. (1972). Approaches to the quantitative analysis of delayed hypersensitivity. Curr. Top. Microbiol. Immunol. $57,75-110$.

Uhr, J. W., and Pappenheimer, A. M., Jr. (1958). Delayed hyper sensitivity. III. Specific desensitization of guinea pigs sensitizeds to protein antigens. J. exp. Med., 108, 891-904.

\section{The August 1973 Issue}

\section{THE AUGUST 1973 ISSUE CONTAINS THE FOLLOWING PAPERS}

Current trends and problems in health screening J. M. G. WILSON

Effects of observer variation in population screening for cervical carcinoma A. LAMBOURNE AND $\mathrm{H}$. LEDERER

Odontogenic myxoma: Ultrastructural and histochemical studies J. D. HARRISON

The incidence of germinal centres in thymus glands of patients with congenital heart disease J. M. VETTERS AND R. J. BARCLAY

A case of chronic granulocytopenia associated with vasculitis and amyloidosis G. H. JENNINGS, A. J. LEVI, AND J. REEVE

An enzyme preparation inactivating all penicillins and cephalosporins PAMELA M. WATERWORTH

The relative susceptibility of four cephalosporins to a beta-lactamase from Bacillus cereus A. D. RUSSELL AND J. R. FURR

Empyema of the gallbladder due to Haemophilus parahaemolyticus, with a brief review of its role as a pathogen MICHAEL PARSONS AND IRWIN FARIS
An outbreak of diphtheria in a hospital for the mentally subnormal G. S. ANDERSON AND J. B PENFOLD

Experimental hypercalcaemia and whole blood clotting P. HILGARD

Fat embolism in sickle cell disease R. M.्ष HUTCHINSON, M. V. MERRICK, AND J. M. WHITE

Evaluation of a tanned cell technique for thyroid microsomal antibodies T. BIRD AND J. STEPHENSONO

Simplification of urinary aldosterone measuremento by radioimmunoassay $\quad$ c. L. COPE AND $S$. LOIZOU

\section{Technical methods}

A simple method for the isolation of blood platelets P. GANGULY AND W. J. SONNICHSEN

Letter to the Editor

Book reviews

Copies are still available and may be obtained from the PUBLISHING MANAGER, BRITISH MEDICAL ASSOCIATION, TAVISTOCK SQUARE, LONDON, WClH 9JR, price $£ 1.05$ 